\title{
Lean and Green Indicators: An Application in the Coffee Sector
}

\author{
Liane Mahlmann Kipper*,Lucas Vinicius Reis, Nícholas Hoffmann, Ana Julia Dal Forno and Fáber D Giraldo \\ University of Santa Cruz by University of Santa Cruz do Sul, Brazil
}

Submission: June 18, 2018, Published: July 13, 2018

"Corresponding author: Liane Mahlmann Kipper, University of Santa Cruz do Sul, Brazil, Email: liane@unisc.br

\begin{abstract}
Linking Lean and Green production systems to better economic, social and environmental results have become a reality in many industrial sectors. The objective of this study is to establish a set of indicators that support the implementation and maintenance of Lean and Green systems in coffee producing properties. Through a literature review, some necessary metrics were defined to evaluate the Lean/Green synergy. A questionnaire was developed to extract the controlled variables, to identify the possibility of implementing performance indicators and to find the best practices of the sector. 53 indicators were found, including two that evaluate the Lean and Green systems together. With the help of experts in the field, 18 indicators were selected for the coffee sector, nine of which were Lean and nine Green indicators. Thus, it was possible to analyze the Lean/Green maturity in the coffee farms through the results obtained with the monitoring of these indicators and the application of a questionnaire. The results indicate that this sector uses Lean/Green practices and monitors important variables of the production process, however, it is necessary to develop studies that allow the joint implementation of the Lean and Green systems. Thus, this study supports the development of a software capable of monitoring the Lean and Green indicators in the coffee sector, allowing to digitize the information and improve the internal flow.
\end{abstract}

Keywords: Lean manufacturing; Green management; Performance indicators; Coffee sector

\section{Introduction}

The Lean production system developed by Taiichi Ohno is directly related to sustainability issues, by various authors [1-4]. These authors have found possibilities of integration between the philosophy of the Lean production system and sustainable production from the environmental, economic and social point of view. Sustainable production is also identified as Green production, or Green system, and Lean production, receives several names, such as Lean Manufacturing or Lean Management.

Sustainable development is a central theme for our era [5], being a subject in the strategic planning of companies and in the academic environment. In this sense, there is a need to improve production systems and improve existing methodologies. Green thinking was born of this need for improvement and its integration into the Lean system has presented good results [6], supplying the need for companies to align commercial practices with principles of environmental sustainability [7].

The objective of this study is to establish a set of indicators that support the implementation and maintenance of Lean and Green systems in coffee producing properties. It is also the focus of this study the integration of these production systems and the support of information for the development of a software that facilitates the evaluation of both systems, enabling a sustainable industry in the context of the revolution 4.0.

Table 1: Search string.

\begin{tabular}{|c|c|c|}
\hline Terms & Operators & Search String \\
\hline Lean & And & \\
\hline Green & Or & $\left.\begin{array}{c}\text { ((Lean and (Green } \\
\text { and (Manufacturing } \\
\text { or Production or } \\
\text { Management) } \\
\text { and (Metrics or } \\
\text { Indicators }\end{array}\right)$ ) $)$ \\
\hline Mroduction & \\
\hline Management & \\
\hline Metrics & \\
\hline
\end{tabular}

A literature review of the Lean and Green systems was carried out to investigate the related works and metrics, already identified by other authors, that allow the evaluation of the synergy between these systems. This review was carried out in the index databases Scopus, Science Direct, Web of Sciense and Springer, and tries to 
answer the research question: "What are the metrics that can measure the Lean/Green synergy?". The selection of papers takes into account the title, abstract, and keywords and used the search terms according to Table 1.

The searches in these international electronic databases were performed using the filters available in the advanced search options. Only articles published between 1996 and 2016 were selected.

The questionnaire in Table 2 was designed to determine some of the variables monitored, to seek the possibility of implementing performance indicators and to identify the best production practices in the sector.

Table 2: Questionnaire to identify good practices.

\begin{tabular}{|c|c|}
\hline Question & Reference \\
\hline Is Just-in-Time practice used? & {$[8,9]$} \\
\hline $\begin{array}{c}\text { Are actions applied to counteract the negative } \\
\text { effects that Just-in-Time can have on the Green } \\
\text { system? }\end{array}$ & {$[10]$} \\
\hline Is Kaizen practice used? & {$[9]$} \\
\hline Is Value Stream Mapping (VSM) practice used? & {$[11,12,13]$} \\
\hline $\begin{array}{c}\text { Are there employees trained to work with these } \\
\text { production systems? }\end{array}$ & {$[14,15]$} \\
\hline $\begin{array}{c}\text { How long have the concepts of these systems } \\
\text { been applied in the company? }\end{array}$ & {$[12]$} \\
\hline $\begin{array}{c}\text { Is Genba Walk practice used? } \\
\text { In the process mapping (VSM), were } \\
\text { environmental variables included? }\end{array}$ & {$[16]$} \\
\hline $\begin{array}{c}\text { Is there a policy of reducing, reusing, and } \\
\text { recycling (The 3Rs)? }\end{array}$ & {$[4]$} \\
\hline $\begin{array}{c}\text { Is there an assessment of opportunities for } \\
\text { improvement in the environmental aspects of the } \\
\text { product in the various phases of its life cycle (Life } \\
\text { Cycle Analysis - LCA)? }\end{array}$ & {$[2]$} \\
\hline $\begin{array}{c}\text { Does the company care about replacing the use of } \\
\text { dangerous products in its processes, and in cases } \\
\text { where substitution is not possible carrying out } \\
\text { the control and monitoring? }\end{array}$ & {$[16]$} \\
\hline
\end{tabular}

The opinion of four Colombian specialists in the coffee sector was collected through an interview with the objective of identifying the main appropriate indicators for the productive sector under study, among all the indicators that were found in the literature review.

\section{Discussion}

From the application of the search filters, 34 articles were obtained in Scopus, 10 in Science Direct, 27 in the Web of Science and no articles were found in Springer. To refine the search, the results were restricted to the research sub-areas: "Engineering", "Business, Management and Accounting" and "Environmental Science" for the Scopus database and related sub-areas for the other databases. Reducing the number of articles to 29 in Scopus and without changing the quantities of the other databases.

To certify that all articles actually address the subject of interest in our research, the title and abstract of the remaining 66 articles have been read. At this stage, 14 articles were excluded because they did not address the topic of our interest and 24 articles were excluded because they were duplicated. We then attempted to download the remaining 28 articles, but from 7 it was not possible to get access to the full text, leaving 21 to be evaluated in more detail.

Through the detailed analysis of the 21 articles, we identified 11 that indicate Lean and Green indicators. In these articles, we identified a set of 53 indicators, which were evaluated by a group of Colombian coffee specialists. The experts selected 18 indicators, nine Lean (Waste per unit of production, Percentage of recycled raw material, Consumption of auxiliary materials, Consumption of raw material, Investments in new equipment, Number of employees in the production process, Cycle time, Labor productivity, and Number of customer complaints) and nine Green (Energy consumption, Water consumption, Initiatives to generate greater efficiency in the use of resources, Total expenditures and investments in environmental protection, Direct emissions (water and soil), Emission reduction, Environmental certification, Risks to employee health and safety, and $\mathrm{CO}_{2}$ emissions per unit produced). Each indicator has one or more variables to perform the calculation.

In addition to these 18 indicators pointed out by experts, two more are indicated, which evaluate both Lean and Green practices, OEEE (Overall Environmental Equipment Effectiveness) and CVE (Carbon-Value Efficiency).

The OEEE indicator is proposed by [17] to include the environmental variable to the variables originally measured by this indicator and to do the Lean/Green measurement. Then we multiply the variable sustainability by the other variables. This last variable is then obtained by dividing the environmental impact of the workstation by the total environmental impact of the initial state of production. The authors suggest other ways to measure sustainability that should be chosen according to the company's preference.

The CVE is introduced by [12] and provides a means to evaluate the performance of the Lean and Green systems, integrating metrics derived from the implementation of both. This indicator tracks value-added time, a widely applicable metric derived from the Lean implementation, and the carbon footprint, which is also a widely known metric of Green implementation. The overall concept of CVE is to track the amount of value-added time created per carbon footprint unit. It gives an indication of the proportion of value-added activities by environmental impact.

The 18 indicators ( 9 Lean and 9 Green) selected by the experts and the two indicators that measure Lean and Green together were organized in Table 3. 


\section{Agricultural Research \& Technology: Open Access Journal}

Table 3: Proposed indicators.

\begin{tabular}{|c|c|c|}
\hline Indicator & Concept & Metric \\
\hline Waste per unit of production & Measures the waste per unit of production. & $\begin{array}{l}\text { Waste generated in one month }(\mathrm{Kg}) / \mathrm{Quantity} \\
\text { produced in one month }(\mathrm{Kg})\end{array}$ \\
\hline Percentage of recycled raw material & $\begin{array}{l}\text { It measures the amount of raw material } \\
\text { recycled in relation to the total of materials } \\
\text { used. }\end{array}$ & $\begin{array}{l}\text { Total value of recycled materials used in one } \\
\text { month }(\$) / \text { Total value of materials used in one } \\
\text { month }(\$)) * 100\end{array}$ \\
\hline Consumption of auxiliary materials & $\begin{array}{l}\text { Measures the consumption of materials that are } \\
\text { not used in the product. }\end{array}$ & $\begin{array}{l}\text { Amount spent on auxiliary materials in one } \\
\text { month (\$) / Quantity produced in one month } \\
\text { (Kg) }\end{array}$ \\
\hline Consumption of raw material & $\begin{array}{l}\text { It measures the amount of raw material used in } \\
\text { the processes. }\end{array}$ & $\begin{array}{l}\text { Total amount spent on raw materials in one } \\
\text { month (\$) / Quantity produced in one month } \\
\text { (Kg) }\end{array}$ \\
\hline Investments in new equipment & $\begin{array}{l}\text { Measures the amount spent on new equipment } \\
\text { for one year. }\end{array}$ & $\begin{array}{l}\text { Amount invested in new equipment in one year } \\
\text { (\$) / Farm size (ha) }\end{array}$ \\
\hline Number of employees in the production process & $\begin{array}{l}\text { It measures the number of employees who are } \\
\text { involved in the production process. }\end{array}$ & $\begin{array}{l}\text { Number of employees directly involved in the } \\
\text { production process / Farm size (ha) }\end{array}$ \\
\hline Cycle time & $\begin{array}{l}\text { It measures the time elapsed from the } \\
\text { beginning of a process to its end. }\end{array}$ & Time required to produce a bag (Hours) \\
\hline Labor productivity & $\begin{array}{l}\text { Measures employee productivity relative to } \\
\text { quantity produced. }\end{array}$ & $\begin{array}{l}\text { (Hours worked in a month * Number of } \\
\text { employees) / Quantity Produced (Kg) }\end{array}$ \\
\hline Number of customer complaints & Measures the number of customer complaints. & $\begin{array}{l}\text { Customer complaints in a month / Quantity } \\
\text { produced in one month (Kg) }\end{array}$ \\
\hline $\begin{array}{l}\text { OEEE (Overall Environmental Equipment } \\
\text { Effectiveness) }\end{array}$ & $\begin{array}{l}\text { Adds the sustainability variable to the overall } \\
\text { equipment efficiency calculation. }\end{array}$ & $\begin{array}{c}\text { OEEE = Availability (\%) x Performance (\%) x } \\
\text { Quality (\%) x Sustainability (\%) }\end{array}$ \\
\hline CVE (Carbon-Value Efficiency) & $\begin{array}{l}\text { Tracks the amount of value-added time created } \\
\text { per carbon footprint unit. }\end{array}$ & Value added time/Total carbon footprint \\
\hline Energy consumption & $\begin{array}{l}\text { It measures the energy consumption used per } \\
\text { unit produced. }\end{array}$ & $\begin{array}{l}\text { Power consumption in one month }(\mathrm{KWh}) / \text { Units } \\
\text { produced in one month }(\mathrm{Kg})\end{array}$ \\
\hline Water consumption & $\begin{array}{l}\text { It measures the water consumption used in the } \\
\text { processes for one month per unit produced. }\end{array}$ & $\begin{array}{l}\text { Water consumption in one month }\left(\mathrm{m}^{3}\right) / \text { Units } \\
\text { produced in one month }(\mathrm{Kg})\end{array}$ \\
\hline $\begin{array}{l}\text { Initiatives to generate greater efficiency in the } \\
\text { use of resources }\end{array}$ & $\begin{array}{l}\text { Number of initiatives created to generate } \\
\text { greater efficiency in the use of resources per } \\
\text { year. }\end{array}$ & $\begin{array}{l}\text { Number of initiatives to optimize resource use } \\
\text { per year/Number of employees }\end{array}$ \\
\hline $\begin{array}{l}\text { Total expenditures and investments in } \\
\text { environmental protection }\end{array}$ & $\begin{array}{l}\text { Measures investments and spending on } \\
\text { environmental protection. }\end{array}$ & $\begin{array}{l}\text { Amount invested in environmental protection } \\
\text { per year (\$)/Size of farm (Ha) }\end{array}$ \\
\hline Direct emissions (water and soil) & $\begin{array}{l}\text { It measures the amount of emissions per unit } \\
\text { produced. }\end{array}$ & $\begin{array}{l}\text { Total waste (solids and liquids) discarded in } \\
\text { water and/or soil (Kg)/Quantity Produced (Kg) }\end{array}$ \\
\hline Emission reduction & Measures the reduction of $\mathrm{CO}_{2}$ emissions. & $\begin{array}{l}\left(\mathrm{CO}_{2} \text { produced in the last period (Ton.) }-\mathrm{CO}_{2}\right. \\
\text { produced in the current period (Ton.))/Farm } \\
\text { size (ha) }\end{array}$ \\
\hline Environmental certification & $\begin{array}{l}\text { It measures the score of the farm achieved in } \\
\text { the environmental certification. }\end{array}$ & Score achieved on last certification (\%) \\
\hline Risks to employee health and safety & $\begin{array}{l}\text { Measures risks to the health and safety of } \\
\text { employees through the number of hours not } \\
\text { worked for health reasons. }\end{array}$ & $\begin{array}{l}\text { (Number of hours not worked per health } \\
\text { reason)/(Monthly load * Number of employees } \\
\text { in the productive process)) } * 100\end{array}$ \\
\hline $\mathrm{CO}_{2}$ emissions per unit produced & $\begin{array}{l}\text { It relates the amount of } \mathrm{CO}_{2} \text { produced per } \\
\text { production performed over a given period of } \\
\text { time. }\end{array}$ & $\begin{array}{l}\mathrm{CO}_{2} \text { produced in one month (Ton.)/Units } \\
\text { produced in one month }(\mathrm{Kg})\end{array}$ \\
\hline
\end{tabular}

The set of indicators defined by the experts was applied in 18 companies in the coffee sector of Colombia and it was verified that only 6 companies in the total sample measure $50 \%$ or more of the suggested variables, which indicates lack of knowledge about production processes and indicators. It was observed that these companies do not carry out the monitoring with direct use of the indicators found in the literature. Only the variables that make up the indicators are measured. There is an attempt to control the processes, but knowledge for more efficient monitoring is still a practical gap in companies.

\section{Conclusion}

Through a literature review and expert opinion, key indicators were found to assess the Lean/Green synergy in the coffee sector. 
Two indicators have been found that evaluate both Lean and Green practices, OEEE (Overall Environmental Equipment Effectiveness) and CVE (Carbon-Value Efficiency).

In addition to the indicators, a questionnaire was developed to find other relevant items. It was observed that although this sector uses Lean and Green practices and monitors important variables of the production process, it is still necessary to know more about these systems and about the use of appropriate indicators for this sector. This study sought to present support to develop a platform capable of monitoring the Lean and Green indicators in the coffee sector. This will allow you to analyze the maturity of the Lean/ Green synergy, digitize information and improve the internal flow of companies.

\section{Acknowledgement}

This study was supported by the double degree agreement between the Master in Systems and Industrial Processes of the University of Santa Cruz do Sul and the Master in Engineering with emphasis on software development at the University of Quindío, Colombia. The authors are grateful to the Coordination for the Improvement of Supplementary Level Personnel (CAPES) and the National Council for Scientific and Technological Development (CNPq), for the scholarships granted. We also thank the coffee growers and the association of Cordilleranos of the state of Quindío that allowed visits to the properties and contributed to the questionnaire.

\section{References}

1. ROLO A, Pires AR, Saraiva M (2014) Supply Chain as a Collaborative Virtual Network Based on LARG Strategy. In: Proceedings of the Eighth International Conference on Management Science and Engineering Management, pp. 701-711.

2. Verrier B, Rose B, Caillaud E, Remita H (2014) Combining organizational performance with sustainable development issues: the Lean and Green project benchmarking repository. Journal of Cleaner Production 85: 83-93.

3. Dhingra R, Kress R, Upreti G (2014) Does Lean mean Green? Journal of Cleaner Production 85: 1-7.

4. Fercoq A, Lamouri S, Carbone V (2016) Lean/Green integration focused on waste reduction techniques. Journal of Cleaner Production 137: 567-578.
5. Sachs JD (2015) The age of sustainable development. Columbia University Press.

6. Jabbour CJC, De Sousa ABL, Govindan K, Teixeira AA, Freitas WRS (2013) Environmental Management and operational performance in automotive companies in Brazil: the role of human resource Management and Lean Manufacturing. Journal of Cleaner Production 47: $129-140$.

7. Caldera HTS, Desha C, Dawes L (2017) Exploring the role of Lean thinking in sustainable business practice: A systematic literature review. Journal of Cleaner Production.

8. Bae JW, Kim YW (2008) Sustainable Value on construction projects and Lean construction. Journal of Green Building 3(1): 156-167.

9. Parveen CM, Kumar AP, Rao TN (2011) Integration of Lean and Green supply chain-Impact on Manufacturing firms in improving environmental efficiencies. Green Technology and Environmental Conservation pp. 143-147.

10. Mollenkopf D, Stolze H, Tate WL, Ueltschy M (2010) Green, Lean, and global supply chains. International Journal of Physical Distribution \& Logistics Management 40(1/2): 14-41.

11. Kurdve M, Shahbazi S, Wendin M, Bengtsson C, Wiktorsson M (2015) Waste flow mapping to improve sustainability of waste Management: a case study approach. Journal of Cleaner Production 98: 304-315.

12. Ruisheng NG, SzeChoong J; Bin S (2015) Integrating and implementing Lean and Green practices based on proposition of Carbon-Value Efficiency metric. Journal of Cleaner Production 95: 242-255.

13. Faulkner W, Badurdeen F (2014) Sustainable Value Stream Mapping (Sus-VSM): methodology to visualize and assess Manufacturing sustainability performance. Journal of Cleaner Production 85: 8-18.

14. Barve A, Muduli K (2013) Modelling the challenges of Green supply chain Management practices in Indian mining industries. Journal of Manufacturing Technology Management 24(8): 1102-1122.

15. Dora M, van Goubergen D, Kumar M, Molnar A, Gellynck X (2014) Application of Lean practices in small and medium-sized food enterprises. British Food Journal 116(1): 125-141.

16. Verrier B, Rose B, Caillaud E (2016) Lean and Green strategy: the Lean and Green House and maturity deployment model. Journal of Cleaner Production 116: 150-156.

17. Rosario D; Sergio A (2015) Overall Environmental Equipment Effectiveness as a Metric of a Lean and Green Manufacturing System. Sustainability 7(7): 9031-9047.

\section{Your next submission with Juniper Publishers will reach you the below assets}

- Quality Editorial service

- Swift Peer Review

- Reprints availability

- E-prints Service

- Manuscript Podcast for convenient understanding

- Global attainment for your research

- Manuscript accessibility in different formats ( Pdf, E-pub, Full Text, Audio)

- Unceasing customer service

Track the below URL for one-step submission https://juniperpublishers.com/online-submission.php 